\title{
Pemberian Lyophilized Bacterial Lysat Pada Penderita Penyakit Paru Obstruktif Kronis Stabil Yang Memiliki Kolonisasi Potentialy Pathogenic Microorganism
}

\author{
Povi Pada Indarta1', Irvan Medison², Russilawati ${ }^{3}$, Deddy Herman ${ }^{4}$
}

\begin{abstract}
Abstrak
Latar Belakang: Eksaserbasi pada pasien PPOK berpengaruh terhadap keparahan penyakit. Kolonisasi bakteri pada pasien PPOK dianggap berkontribusi terhadap kejadian eksaserbasi. Usaha menurunkan kolonisasi bakteri dilakukan untuk mengurangi kejadian eksaserbasi salah satuanya adalah dengan vaksinasi. Tujuan dari penelitian ini adalah untuk melihat efek pemberian vaksinasi Lyophilized bacterial lysat pada pasien yang telah diketahui jenis potentialy pathogenic microorganism (PPM).Metode: Desain penelitian uji klinis terbuka (open ckinical trial) pada pemberian Lyophilized bacterial lysate dibandingkan dengan Plasebo terhadap pasien PPOK dengan koloni PPM di poliklinik Paru RSUP Dr.M.Djamil Padang periode Januari sampai Juni 2017.Sampel diambil dengan teknik konsekutif (accidental sampling). Hasil: Penelitian pada 33 pasien PPOK stabil dengan PPM yang diberikan Lyophilized bacterial lysat dan 22 pasien PPOK stabil dengan PPM yang diberika plasebo. Setelah perlakuan selama 3 bulan pada kelompok Lyophilized bacterial lysat tidak ditemukan lagi koloni bakteri ganda (10 menjadi 10) $(p=0,002)$ sedangkan pada bakteri tunggal masih ditemukan koloni, sebelum 23 menjadi 26. Kelompok plasebo tidak didapatkan perubahan baik bakteri ganda (13 menjadi 13) ataupun tunggal (9 menjadi 9). Pada kelompok Lyophilized bacterial lysat terjadi perubahan pola koloni yaitu klebsiella pneumonia berkurang 6, Pseudomonas Aureginosa berkurang 2, Stapilococcus Areus berkurang 6, secara statistik mengalami penurunan $(p=0,001)$ sedangkan pada plasebo tidak terjadi perubahan pola koloni Simpulan: Lyophilized bacterial lysat menurunkan proporsi koloni PPM oleh bakteri ganda dibandingkan dengan plasebo. Lyophilized bacterial lysat juga mengurani koloni terutama Pseudomonas Aureginosa dan stapylococcus Aureus dan klebsiella pneumonia.
\end{abstract}

Kata kunci: PPOK, kolonisasi, Lyophilized bacterial lysate.

\begin{abstract}
Background: Exacerbations in COPD patients influence the severity of the disease. Bacterial colonization in COPD patients is considered to contribute to the incidence of exacerbations. Efforts to reduce bacterial colonization are carried out to reduce the incidence of exacerbations, one of which is vaccination. The purpose of this study was to find out the effect of the administration of Lyophilized bacterial lysat in patients with known type with potentialy pathogenic microorganism in their sputum. Method: Open clinical trial in efect of Lyophilized bacterial lysate compare to Plasebo In COPD patient with PPM colony. The study performed in Dr. M. Djamil Hospital Padang from January to June 2017. Subject were taken by accidental sampling. Results: We Administored Lyophilized bacterial lysate on 33 stable COPD with PPM and Plasebo on 22 stable COPD patient with PPM. After treatment for 3 months in the the propotional multy bacterial colony on PPM decrease in Lyophilized bacterial lysate group (10 to 10) $p=0.002$ Whereas colony was found in single bacteria before (23 to 26). The placebo group did not change either multy bacterial colony. Colony of Klebsiella Pneumonia (-6), Pseudomonas Aureginosa (-2), Stapilococcus Areus (-6) statisticaly significant decrease $(p=0,001)$. Conclusion: Lyophilized bacterial lysate could decreased potential pathogenic microorganism by multy bacterial in patients with stable COPD placebo. Lyophilized bacterial lysat also reduces potential colonies of pathogenic microorganism especially, klebsiella pneumoniae, staphylococcus aureus and pseudomonas aeruginosa.
\end{abstract}

Keywords: COPD ,colonization, Lyophilized bacterial lysate

Affiliasi penulis :1.RSUD Abdoel Madjid Batoe Jambi, 2.RSUP Dr M Djamil Padang , 3. Fakultas kedokteran Univ Andalas 4 Fakultas Kedokteran Univ Andalas / RSAM

Korespondensi : povipadaindarta@gmail.com Telp: 08122173

\section{PENDAHULUAN}

World Health Organization (WHO) melaporkan pada tahun 2002 PPOK menempati urutan ke-5 sebagai penyebab utama kematian di dunia dan diperkirakan akan menjadi penyebab kematian ke-3 didunia pada tahun 2030 selain kanker dan penyakit kardiovaskuler. ${ }^{1} \mathrm{Di}$ Indonesia menurut the Asia pasific COPD round table group 
memperkirakan pravelensi penderita PPOK sekitar 5,6\%. ${ }^{2}$ Eksaserbasi pada pasien PPOK berpengaruh terhadap keparahan penyakit. Saluran nafas bagian bawah dalam keadaan sehat adalah steril, tapi pada pasien PPOK stabil bakteri dapat diisolasi dalam proporsi yang signifikan sebagai kolonisasi bakteri pada saluran nafas bawah. ${ }^{3}$ Kolonisasi bakteri pada pasien PPOK dianggap berkontribusi terhadap kejadian eksaserbasi. Usaha untuk menurunkan kolonisasi bakteri dilakukan untuk mengurangi kejadian eksasebasi salah satunya adalah dengan vaksinasi. Tujuan dari penelitian ini adalah untuk melihat efek pemberian vaksinasi Lyophilized bacterial lysat pada pasien yang telah diketahui jenis PPM pada sputumnya.

\section{METODE}

Desain Penelitian ini merupakan suatu uji klinis terbuka (open clinical trial). Dengan pemberian obat Lyophilized bacterial lysat (LBL) sebanyak 33 kasus dan Plasebo pada 22 plasebo yang ditemukan Potentially Pathogenic microorganism (PPM) pada sputum pasien PPOK stabiL. Subjek setuju untuk mengikuti penelitian yang memenuhi kriteria inklusi. Prosedur pemberian obat penelitian pemberian Lyophilized bacterial lysate dengan dosis $7 \mathrm{mg}$ dan plasebo selama 10 hari dalam satu bulan selama 3 bulan berturut-turut. Analisis statistik untuk data kategorik diuji dengan uji chi-square apabila syarat Chi-Square terpenuhi sedangkan apabila tidak terpenuhi maka digunakan uji Exact Fisher untuk tabel $2 \times 2$ dan Kolmogorov Smirnov. Adapun kriteria kemaknaan yang digunakan adalah nilai $p$, apabila $p \leq 0,05$ signifikan atau bermakna secara statistika, dan $p>0,05$ tidak signifikan atau tidak bermakna secara statistik.

\section{HASIL}

Pada kelompok LBL dan plasebo, masingmasing Untuk rata-rata umur sebesar 65,67 $\pm 8,536$ dan 65,59 $\pm 7,433$, laki-laki 59 (95,2\%)dan 61 (98,4\%) Pasien yang merokok $22(35,5 \%)$ dan 12 (19,4\%), berhenti merokok $38(61,3 \%)$ dan 50 (80,6\%), Tidak merokok $2(3,2 \%)$ dan $0 \quad(0,0 \%)$ dengan lama merokok rata-rata selama $42,98 \pm 8,163$ dan $45,35 \pm 9,145$, Indeks Brinkman Berat 55 (88,7\%) dan 60 (96,8\%), Dari hasil analisis perbandingan karakteristik kedua kelompok diatas terdapat variabel yang memiliki nilai $\mathrm{p}<0,05$, maka dapat disimpulkan kedua kelompok berbeda atau ada perbedaan karakteristik pada saat awal pemeriksaan. Hal ini menunjukkan kedua kelompok tidak homogen.

Tabel 2 memperlihatkan perbandingan perubahan proporsi pasien kolonisasi PPM pada penderita PPOK stabil kelompok Lyophilized bacterial lysat dan placebo sebelum dan setelah perlakuan. Pada kelompok lyophilized bacterial lysat setelah pemberian LBL selama 3 bulan tidak ada lagi koloni bakteri ganda, dimana dari 10 penderita yang ditemukan bakteri ganda setelah diberikan LBL tidak ditemukan lagi kolonisasi ganda sebanyak 7 orang dan berubah menjadi bakteri tunggal sebanyak 3 orang $10(30,3 \%)$ dan $0(0 \%)$. Kelompok bakteri tunggal yang mendapatkan LBL meningkat sebanyak 3 orang dimana ini disebakan perubahan dari bakteri ganda yang berubah menjadi bakteri tunggal setelah mendapatkan LBL 23 (69,7\%) dan 26 (100\%). Kelompok plasebo sebelum perlakuan, pola kolonisasi tidak didapatkan perubahan proporsi baik bakteri ganda ataupun tunggal sebanyak $13(59,1 \%)$ dan 13 $(51,9 \%)$ Bakteri tunggal sebanyak $9(40,9 \%)$ dan 9 $(40,9 \%)$.

Nilai P pada variabel pola kolonisasi sebelum dan sesudah perlakuan kelompok Lyophilized bacterial lysat lebih kecil dari 0.05 (nilai $\mathrm{P}<0.05$ ) yang berarti signifikan atau bermakna secara statistik. Terdapat perbedaan proporsi yang signifikan secara statistik antara variabel pola kolonisasi sebelum dan sesudah perlakuan pada kelompok Lyophilized bacterial lysat sedangkan pada kelompok placebo dengan nilai plebih besar dari 0.05 (nilai $P>0.05$ ) yang berarti tidak signifikan atau tidak bermakna secara statistik.

Tabel 3 memperlihatkan perbandingan antara pola Kolonisasi bakteri sebelum dan sesudah perlakuan pada kelompok Lyophilized bacterial lysat dan Placebo. Kelompok Lyophilized bacterial lysat Pada Kelompok Lyophilized bacterial lysat sebelum dan sesudah perlakuan didapatkan terjadi perubsahan pada Kolonisasi bakteri Klebsiella Pneumoniae terjadi penuruanan koloni sebanyak 6, bakteri Pseudomanas Aureginosa terjadi penurunan koloni 2, bakteri Staphilococcus Aureusv mengalami penurunan kolonisasi sebanyak 6 sedangkan bakteri 
Haemophilus Influenzae, Staphilococcus Epidermidis dan Steptococcus Pyogenes tidak terjadi penurunan koloni sedangkan pada kelompok Plasebo bakteri Haemophilus Influenzae, Klebsiella Pneumoniae, Pseudomanas Aureginosa, Staphilococcus Epidermidis, Steptococcus Pyogenes dan Staphilococcus Aureus tidak terjadi perubahan koloni _Secara keseluruhan perubahan koloni sebelum dan sesudah pada kelompok yang diberikan lyophilized bacterial lysat terjadi penurunan secara signifikan dengan nilai $\mathrm{P}<0.05$ terutama pada koloni bakteri Klebsiella Pneumoniae, Pseudomanas Aureginosa, Stapylococcus Aureus sedangkan kelompok placebo secara statistik tidak terdapat punurunan koloni sebelum dan sesudah perlakuan.

Tabel 1. Karakteristik Dasar Pasien PPOK

\begin{tabular}{|c|c|c|c|}
\hline \multirow{2}{*}{$\begin{array}{l}\text { Karakteristik } \\
\text { Subjek }\end{array}$} & \multicolumn{2}{|c|}{ Kelompok } & \multirow{2}{*}{$P$ valu } \\
\hline & Kasus $\mathrm{N}=62$ & Kontrol N=62 & \\
\hline Jenis kelamin & & & 0.619 \\
\hline Laki-laki & $59(95,2 \%)$ & $61(98,4 \%)$ & \\
\hline Perempuan & $3(4,8 \%)$ & $1(1,6 \%)$ & \\
\hline Umur (tahun) & & & 0,955 \\
\hline Mean \pm Std & $65,67 \pm 8,536$ & $65,59 \pm 7,433$ & \\
\hline Median & 66,00 & 66,00 & \\
\hline Range (min-max) & $49,00-87,00$ & $50,00-80,00$ & \\
\hline Status merokok & & & 0,395 \\
\hline Merokok & $22(35,5 \%)$ & $12(19,4 \%)$ & \\
\hline Berhenti merokok & $38(61,3 \%)$ & $50(80,6 \%)$ & \\
\hline Tidak merokok & $2(3,2 \%)$ & $0(0,0 \%)$ & \\
\hline Indeks Brinkman & & & 0,163 \\
\hline Berat & $55(88,7 \%)$ & $60(96,8 \%)$ & \\
\hline Sedang & $7(11,3 \%)$ & $2(3,2 \%)$ & \\
\hline \multicolumn{4}{|l|}{ Spirometri } \\
\hline VEP1 & & & 0,065 \\
\hline $\begin{array}{l}\text { Mean } \pm \text { Std } \\
\text { Median }\end{array}$ & $\begin{array}{l}1053,90 \pm 809 \\
638 \\
898,50\end{array}$ & $\begin{array}{l}1457,85 \pm 1215 \\
.576 \\
1225,00\end{array}$ & \\
\hline Range (min-max) & $\begin{array}{l}230,00- \\
6400,00\end{array}$ & $\begin{array}{l}330,00- \\
7200,00\end{array}$ & \\
\hline KVP & & & 0,070 \\
\hline Mean \pm Std & $\begin{array}{l}1821,00 \pm 685 \\
195\end{array}$ & $\begin{array}{l}2226,38 \pm 968 \\
819\end{array}$ & \\
\hline Median & 1805,00 & 2110,00 & \\
\hline Range (min-max) & $\begin{array}{l}650,00- \\
3650,00\end{array}$ & $\begin{array}{l}330,00- \\
7740,00\end{array}$ & \\
\hline VEP1/KVP & & & 0,745 \\
\hline Mean \pm Std & $53,23 \pm 10,516$ & $52,65 \pm 10,758$ & \\
\hline Median & 51,45 & 51,46 & \\
\hline Range (min-max) & $21,30-86,45$ & $31,13-69,90$ & \\
\hline $\begin{array}{l}\text { Skala Sesak Napas } \\
\text { (mMRC) }\end{array}$ & & & 0,988 \\
\hline Skala 2 & $32(51,6 \%)$ & $37(59,7 \%)$ & \\
\hline Skala 3 & $26(41,9 \%)$ & $25(40,3 \%)$ & \\
\hline Skala 4 & $4(6,5 \%)$ & $0(0,0 \%)$ & \\
\hline $\begin{array}{l}\text { Proporsi } \\
\text { Kolonisasi }\end{array}$ & & & $0.034^{\star *}$ \\
\hline BakteriGanda & $10(30,3 \%)$ & $13(59,1 \%)$ & \\
\hline Bakteri tunggal & $23(69,7 \%)$ & $9(40,9 \%)$ & \\
\hline $\begin{array}{l}\text { Kolonisasi Bakteri } \\
\text { sebeperlakuan }\end{array}$ & & & \\
\hline HaemophilusInfluenz & $8(19,5 \%)$ & $5(15,6 \%)$ & \\
\hline KlebsiellaPneumonia & $12(29,3 \%)$ & $8(25,0 \%)$ & \\
\hline
\end{tabular}

\begin{tabular}{lll}
\hline PseudomanasAuregi & $8(19,5 \%)$ & $11(34,4 \%)$ \\
StaphilococcusAure & $11(26,8 \%)$ & $6(18,8 \%)$ \\
StaphilococcusEpide & $1(2,4 \%)$ & $2(6,3 \%)$ \\
SteptococcusPyoge & $1(2,4 \%)$ & $0(0,0 \%)$
\end{tabular}

Tabel 2. Perubahan Proporsi Pasien dengan Kolonisasi PPM pada Penderita PPOK Stabil Kelompok Lyophilized Bacterial Lysat dan Plasebo

\begin{tabular}{|c|c|c|c|c|c|c|}
\hline \multirow{2}{*}{ Variabel } & \multicolumn{2}{|c|}{$\begin{array}{l}\text { Lyophilized } \\
\text { bacterial lysat }\end{array}$} & \multirow{2}{*}{$\underset{P}{\text { Nilai }}$} & \multicolumn{2}{|c|}{ Placebo } & \multirow{2}{*}{$\underset{P}{\text { Nilai }}$} \\
\hline & Sebelun & Sesudah & & Sebelum & Sesudah & \\
\hline $\begin{array}{c}\text { Pola } \\
\text { Kolonisasi }\end{array}$ & & & $0,002^{* *}$ & & & 1,000 \\
\hline \multirow{2}{*}{$\begin{array}{l}\text { Bakteri } \\
\text { Ganda }\end{array}$} & 10 & 0 & & 13 & 13 & \\
\hline & $(0,3 \%)$ & $(0,0 \%)$ & & $(59,1 \%)$ & $(59,1 \%)$ & \\
\hline \multirow{2}{*}{$\begin{array}{l}\text { Bakteri } \\
\text { Tunggal }\end{array}$} & 23 & 26 & & 9 & 9 & \\
\hline & $(69,7 \%)$ & $(100.0 \%)$ & & $(40,9 \%)$ & $(40,9 \%)$ & \\
\hline
\end{tabular}

Tabel 3. Pola perubahan Kolonisasi PPM pada Penderita PPOK Stabil yang memiliki PPM pada Lyophilized bacterial lysat Dan Plasebo

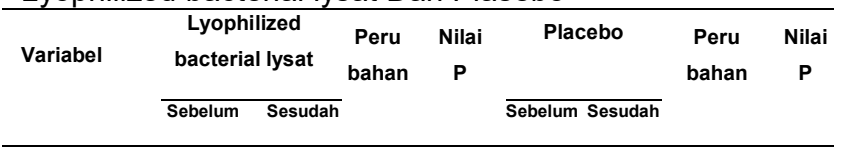

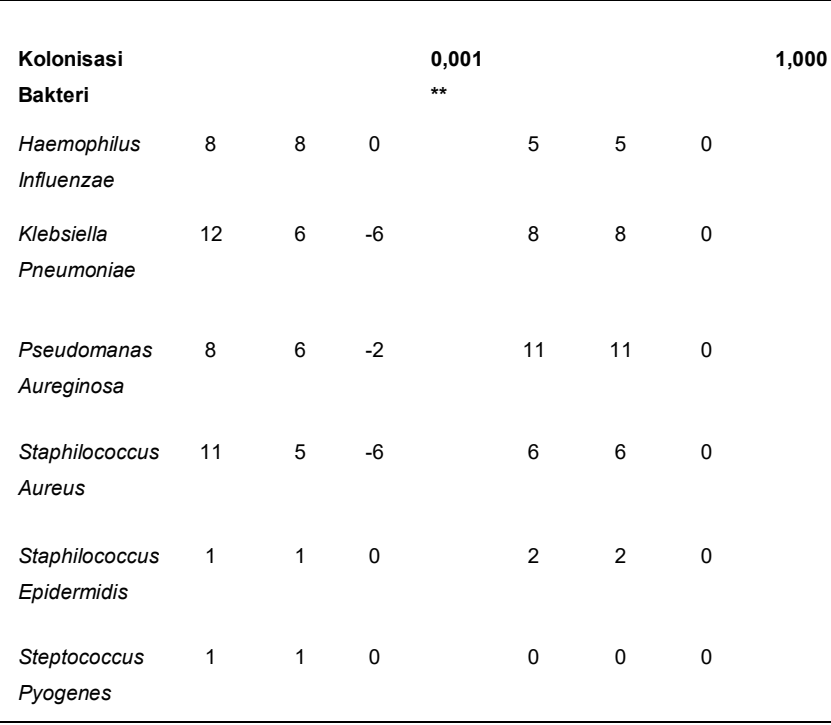

\section{PEMBAHASAN}

Penelitian ini dengan subjek berjumlah 33 subjek pasien PPOK stabil kelompok perlakuan dan 22 subjek pasien PPOK stabil kelompok plasebo. Karakteristik subjek sesuai dengan tabel 1 yaitu pada kelompok perlakuan dan plasebo sebagian subjek adalah laki-laki. Hal yang sama juga didapatkan oleh Arslan $\mathrm{dkk}^{4}$ di Istanbul Turki sebanyak $80 \%$ PPOK stabil berjenis kelamin laki-laki Umur rerata pasien PPOK pada penelitian ini kelompok perlakuan dan plasebo adalah 60tahun. Penelitian lain mendapatkan hasil yang hampir sama seperti Miravitles dkk dan Sitompul $^{5}$ di RS Persahabatan Jakarta. Menurut 
kepustakaan pravalensi PPOK lebih banyak terjadi pada usia dekade keenam atau lebih dan diagnosis PPOK lebih sering ditegakan setelah umur 60 tahun. ${ }^{6,7}$

Pemberian Lyophilized bacterial lysate dapat menurunkan proporsi potential pathogenic microorganism pada penderita PPOK stabil. Hasil penelitian ini menggambarkan ada hubungan pemberian Lyophilized bacterial lysate terhadap proporsi potential pathogenic microorganism pada penderita PPOK stabil. Penelitian ini juga sama dengan penelitian yang dilakukan oleh $\mathrm{F}$ Braido dkk menunjukkan bahwa pemberian Lyophilized bacterial lysate dapat menjadi efek protektif dalam menurunkan bakteri pada seseorang yang mengalami infeksi paru. ${ }^{8}$

Penelitian yang sama juga dilakukan oleh Olaf Zagolski mendapatkan bahwa terjadi pengurangan kolonisasi bakteri Streptococcus pneumonia setelah pemberian Lyophilized bacterial lysate $\quad(p<0,01) .^{9} \quad$ Emmerich dkk melakukan pemeriksaan mikrobiologi Bronko alveolar lavage (BAL) pada 23 pasien, semua kasus dievaluasi semiquantitative setelah pemberian Lyophilized bacterial lysate hanya 2 pasien memiliki lebih dari 50 koloni $H$. influenza dan S. Aureus. ${ }^{10}$ Bronchovaxom (lisat bakteri) merupakan ekstrak imunoaktif terliofilisasi yang terstandarisasi yang bekerja pada sistem imun spesifik terdiri dari 8 spesies (21 strains) bakteri yang paling sering menimbulkan infeksi saluran napas seperti: Streptococcus pneumoniae(4), Streptococcus pyogenes(1), Streptococcusviridans(3), Staphylococcus aureus(6), Klebsiella pneumoniae (2), Klebsiella ozone (1), Moraxella catarrhalis (3), Haemophilus influenzae (1). ${ }^{10}$ Mekanisme kerja dari lisat bakteri ini dengan memperkuat aktifitas basal respon imun melalui makrofag dan sel dendritik serta meningkatkan kadar antibody paru pada pasien dengan penyakit saluran napas menstimulasi sistem imun secara termodulasi sehingga saat terpajan kuman kembali dengan mudah dikenal oleh sistem imun spesifik, sehingga menghasilkan penurunan frekuensi dan tingkat keparahan infeksi saluran napas, dan eksaserbasi. ${ }^{10}$

Analisis pola kolonisasi menunjukkanbahwa bakteri terbanyak setelah perlakuan adalah Haemophilus influenza ada kelompok kasus dan Pseudomanas aureginosa pada kelompok plasebo.
Penelitian serupa didapat pada penelitian Rossel dkk kolonisasi PPM baik pada PPOK stabil adalah $H$ influenza kemudian diikuti Pseudomanas aureginosa. ${ }^{12}$ Patel dkk pada PPOK stabil terbanyak ditemukan $H$ influenza. ${ }^{13}$ Penyebab lain kemungkinan adanya perbedaan pola kuman pada masing masing daerah. Walaupun ada perbedaan bahwa semua penelitian mendapatkan yang terbanyak adalah Haemophilus influenza dan Pseudomanas aureginosa. Menurut kepustakaan bahwa kolonisasi PPM yang banyak ditemukan pada PPOK stabil Bakteri $H$. influenza kemudian diikuti oleh $S$. pneumoni, $M$. catarhallis dan $P$. aureginosa. ${ }^{14}$

\section{SIMPULAN}

Lyophilized bacterial lysat menurunkan proporsi pasien dengan kolonisai PPM bakteri ganda dibandingkan dengan plasebo dan juga menurunkan kolonisasi koloni bakteri terutama klebsiella pneumonia, pseudomonas aureginosa dan Stapylococcus aureus.

\section{DAFTAR PUSTAKA}

1. Chapman KR, Manninodm, Soriano JBVermiere PA, Buist AS, Thun MJ ,et al. Epedimiology and cost of COPD. EurRespir J. 2006; 27:188-207

2. Sethi S Murphy TF . Infection in Pathogenesis and course of Chronic Obstructive Pulmonary Disease. The New England Journal of Medicine. 2008; 359: 2355-65.

3. Tang $H$, Fang Z, Saborio G B, Xiu Q. Efficacy and safety of OM-85 on Patient with Chronic bronchitis and/or chronic obstructive pulmonary diseases. Lung. 2015; 10:9737-43.

4. Arslan RS, Ozdemir L, Yilmaz B, Unal O, Akkaya E. CRP association betwen C Reactive Protein and Chrinic ObsriuctivePulmonary Disease. Jour Clin Anal Med 2013; 4:120-3.

5. O'Donnel D, Banzett R, Kohlman V, Casaburi R, Davenport PW, Gandevia SC et al. Pathophysiology of dyspnea in chronic obstructive pulmonary disease. Proc Am Thorax Soc 2007; 4:p.145-68.

6. Mahler DA. Mechanism and measurement of dysnea in COPD. Proc Am ThoracSoc. 2006; 3:p.234-38. 
7. Sitompul P.A. hubungan kolonisasi bakteri jalan nafas bawah dengan inflamasi, fungsi paru dan klinis pada penyakit paru obstruktif kronik stabil. Tesis.Jakarta: Bagian Pulmonologi dan kedokteran Respirasi FK UI; 2008.

8. Braido F, Tarantini F, Ghiglione V, Melioli G, Canonica GW .Bacterial lysate in the prevention of acute exacerbation of COPD and in respiratory recurrent infections International Journal of COPD. 2007; 2(3):335-45.

9. Zagólski O, Stręk P, Kasprowicz A, Białecka A Effectiveness of Polyvalent Bacterial Lysate and Autovaccines Against Upper Respiratory Tract Bacterial Colonization by Potential Pathogens: A Randomized Study. Med Sci Monit. 2015; 21:29973002.

10. Emmerich B, Emslander HP, Pachman K, Hallek M, Milatovic D, Busch R. Local immunity in patient with chronic bronchitis and the effect of a bacterial extrac, Broncho-Vaxom,on T Limphocytes, macrophages, Gamma-interferon and secretory Imunoglobulin A in Bronchoalveolar lavage fluid and other Variabels. Respiration. 1990; 57:90-9

11. Massage SD, Johnston SL. Infection. In: Barnes $P$, Drazen J, Rennard S, Thomson N, ed. Asthma and COPD. USA: Academic Press; 2009. p.456-78.

12. Rosel A, Monso E, Soler N, Torres F, Angrill J, Riise $G$, et all. Microbiologic determinant of exacerbation in chronic obstructive pulmonary desease. Arch Intern Med. 2006; 165:891-7.

13. Patel IS, Seemungal TAR, Wilk M, Owen SJL, Donaldson GC, Wedzicha JA. Relationship between bacterial colonization and the frequency, character and severity of COPD exacerbation. Thorax. 2002; 57:759-64.

14. Perhimpunan Dokter Paru Indonesia. Penyakit Paru Obstruktif Kronik (PPOK), Diagnosis dan Penatalaksanaan. PDPI; Jakarta: 2016. 